\title{
Cytotoxicity Effects of Lactobacillus acidophilus on Hep G2 Cell Line and its Effects on Gene Regulation with Bax and Bcl2
}

\author{
N. G. Ramesh Babu ${ }^{1}$, K. A. Simrah Fathima ${ }^{2} *$ V. Nandhini ${ }^{3}$ and V. Nandhini ${ }^{4}$ \\ Department of Biotechnology, Adhiyamaan College of Engineering, Hosur, Tamilnadu, India \\ *Corresponding author
}

\begin{abstract}
A B S T R A C T
The microorganisms most commonly used as probiotics are lactic acid bacteria, especially

those of the genus Lactobacillus. In the present study, Lactobacillus acidophilus were isolated from two different pooled samples homemade curd and commercial curd, were characterized for their antiproliferative activity. The antiproliferative effects of the strains were investigated using the MTT assay with liver cancer (Hep G2) cell line. The results showed that the Lactobacillus strains had good antiproliferative effects in liver cancer cell line. Further the viability of cells was observed with the help of fluorescent microscopy by dual staining technique. Lactobacillus acidophilus can be considered as potential probiotic bacteria for humans because of their antiproliferation effect in cancer cells. In this study, effect of the samples on expression of $\mathrm{Bax}$ and $\mathrm{Bcl} 2$ gene was analysed by RT -PCR. $\beta$ Actin was chosen as an internal control to normalize the gene expression. The study indicate that the MTT assay for the strains of Lactobacilus acidophilus isolated from the sample has cytotoxicity effect. Based on the $\mathrm{IC}_{50}$ value, homemade curd showed better percent of inhibition than commercial curd and $\mathrm{Bcl} 2$ gene showed fold up regulation when compared to Bax gene.
\end{abstract}

\section{Keywords}

Probiotic;

Lactobacillus;

Antiproliferation;

Hep G2; Bax and

$\mathrm{Bcl} 2$ gene

Article Info

Accepted:

05 April 2020

Available Online:

10 May 2020

\section{Introduction}

Probiotics are live microorganisms which, when administered in adequate amounts, confer a health benefit on the host. The most commonly used probiotics in the food industry are Lactic acid bacteria, including the genus Lactobacillus. Probiotics have become highly recognized as supplements for human consumption because of their beneficial effects on health and well-being. For example, interference with pathogens and the prevention of infections, immune system stimulation and immunomodulation, anticarcinogenic and antioxidant activities, reduction of gastrointestinal disorders such as diarrhoea, constipation and the irritable bowel syndrome, alleviation of allergic and lactose intolerance symptoms, reduction in serum cholesterol, blood pressure and risk of gestational diabetes (Dicks LMT and Botes M, 2010).

Among these effects, the antiproliferative or 
cytotoxic effect of probiotic strains against cancer cells is a very important and relatively recent aspect. This probiotic property is important because cancer is considered as the major course of worldwide morbidity (Parisa Shokryazdan et al., 2017).

The MTT system is used to measure the activity of living cells via mitochondrial dehydrogenases. The key component is (3-[4, 5- dimethylthiazol-2-yl]-2, 5-diphenyl tetrazolium bromide) or MTT, is a water soluble tetrazolium salt. This exhibits a yellow colour when prepared in media lacking phenol red. Insoluble purple formazan is formed from dissolved MTT by cleavage of the tetrazolium ring by mitochondrial dehydrogenase enzymes of viable cells.

This water insoluble formazan can be solubilized using DMSO, acidified isopropanol or other solvents (Pure propanol or ethanol). The result of the purple solution was measured spectrophotometrically. The concomitant change in the amount of formazan formed can be visualized by an increase or decrease in the cell number, indicating the degree of effects caused by the test material.

In the present study, Lactobacillus acidophilus were isolated from the two different pooled samples, homemade curd and commercial curd and used to investigate their antiproliferation effects against liver cancer (Hep G2) cell line and the effect of the samples on expression of Bax and $\mathrm{Bcl} 2$ gene was analysed by performing RT -PCR.

The main aim and objectives of this study includes that to isolate the probiotic bacterium from homemade curd and commercial curd. Also to determine the cytotoxicity effect of the samples on Hep G2 cell line. And to analyze the gene regulation with Bax and $\mathrm{Bcl} 2$ gene for the samples.

\section{Materials and Methods}

\section{Collection of samples}

Homemade curd and commercial curd were collected from the local outlets of Bengaluru, Karnataka, India.

\section{Media preparation}

MRS (De Mann, Rogosa , Sharpe ) - 6.16g/L autoclaved at $121^{\circ} \mathrm{C}$ for $15 \mathrm{~min}$. After incubation, MRS were allowed to cool and poured it into sterile petriplate.

\section{Isolation of bacteria}

Samples $(100 \mu \mathrm{L})$ of homemade curd and commercial curd were serially diluted using sterile phosphate buffer. Serially diluted samples $\left(10^{-2}\right)$ and $\left(10^{-3}\right)$ were placed on MRS agar plates by spread plate technique. The plates were incubated at $37^{\circ} \mathrm{C}$ for $48 \mathrm{hrs}$ and observed for colonies. Bacterial colonies were purified by subsequent subcultures (Sahar Karami et al., 2017).

\section{Antiproliferation assay}

\section{Sample preparation}

For cytotoxicity studies, organism concentration was maintained to OD 0.1 and cultured in $5 \mathrm{~mL}$ MRS broth for $48 \mathrm{hrs}$. Later organisms were heat killed for $10 \mathrm{~min}$ at $80^{\circ} \mathrm{C}$. Cells were homogenized thoroughly and were centrifuged at $5000 \mathrm{~g}$ for $5 \mathrm{~min}$. Cell free supernatants of Lactobacillus strain were collected and two fold dilutions of the broth was carried out using DMEM.

\section{Cell culture}

Hep G2 cell lines were procured from American type culture collection (ATCC), stock cells were cultured in DMEM supplemented with $10 \%$ inactivated Fetal 
Bovine Serum (FBS), penicillin (100 IU/mL), streptomycin $(100 \mu \mathrm{g} / \mathrm{mL})$ in a humidified atmosphere of $5 \% \mathrm{CO}_{2}$ at $37{ }^{\circ} \mathrm{C}$ until confluent. The cell was dissociated with cell dissociating solution (0.2\% trypsin, $0.02 \%$ EDTA, $0.05 \%$ glucose in PBS). The viability of the cells are checked and centrifuged. Further, 50,000 cells/well was seeded in a 96 well microtitre plate and incubated for $24 \mathrm{hrs}$ at $37^{\circ} \mathrm{C}$ in $5 \% \mathrm{CO}_{2}$ incubator (Maryam Poormontaseri et al., 2017).

\section{MTT assay}

The monolayer cell culture was trypsinized and the cell count was adjusted to $5.0 \times 10^{5}$ cells/mL using DMEM containing $10 \%$ FBS. To each well of the 96 well microtiter plate, $100 \mu \mathrm{L}$ of the diluted cell suspension $(50,000$ cells/well) was added. After $24 \mathrm{hrs,} \mathrm{the} \mathrm{partial}$ monolayer was formed and the supernatant was flicked off. The monolayer was washed once with medium and $100 \mu \mathrm{L}$ of different concentrations of samples were added on to the partial monolayer in microtiter plates. The plates were then incubated at $37{ }^{\circ} \mathrm{C}$ for $24 \mathrm{hrs}$ in $5 \% \mathrm{CO}_{2}$ atmosphere. After incubation the solutions in the wells were discarded and 100 $\mu \mathrm{L}$ of MTT $(5 \mathrm{mg} / 10 \mathrm{~mL}$ of MTT in PBS) was added to each well. The plates were incubated for $4 \mathrm{hrs}$ at $37{ }^{\circ} \mathrm{C}$ in $5 \% \mathrm{CO}_{2}$ atmosphere. The supernatant was removed and $100 \mu \mathrm{L}$ of DMSO was added and the plates were gently shaken to solubilize the formed formazan. The absorbance was measured using a microplate reader at a wavelength of $590 \mathrm{~nm}$. Doxorubicin was used as standard. The percentage growth inhibition was calculated using the following formula (Nimmy kumar et al., 2016)

$\%$ Inhibition $=[(\mathrm{OD}$ of Control $-\mathrm{OD}$ of sample)/OD of Control] x 100

\section{Statistical evaluation}

IC $_{50}$ Value

The $\mathrm{IC}_{50}$ of a sample was determined and the effect examined at different concentrations of samples. $\mathrm{IC}_{50}$ values can be calculated by determining the concentration needed to inhibit half of the maximum biological response. $\mathrm{IC}_{50}$ values for cytotoxicity tests were derived from a nonlinear regression analysis (curve fit) based on sigmoid dose response curve (variable) and computed using Graph Pad Prism 6 (Graph pad, SanDiego, CA, USA)

\section{Nonlinear regression}

In statistics, nonlinear regression is a form of regression analysis in which observational data are modelled by a function which is a nonlinear combination of the model parameters and depends on one or more independent variables. The data are fitted by a method of successive approximation.

\section{Acridine orange and ethidium bromide dual staining}

Dual acridine orange and ethidium bromide (AO/EB) fluorescent staining, visualized under a fluorescent microscope (Kuan Liu et al., 2015). $25 \mu \mathrm{L}$ (approx. $1 \times 10^{5}$ cells) of treated and untreated cells were taken separately in a micro centrifuge tubes and is stained with $5 \mu \mathrm{L}$ of $\mathrm{AO}-\mathrm{EtBr}$ (Acridine orange and Ethidium Bromide) for about 2 min followed by gentle mixing. $10 \mu \mathrm{L}$ of cell suspension is placed onto a microscopic slide and covered with a glass coverslip and examined in a fluorescence microscope using a fluorescein filter.

\section{Gene regulation using Bax and $B c 12$ gene}

\section{Extraction of RNA}

Total RNA from Hep G2 cells was extracted using TRIzol Reagent (Invitrogen,) according to the manufacturer's instructions. The cells were washed twice with PBS and centrifuged at $2000 \mathrm{~g}$ for $5 \mathrm{~min}$. To the cell pellet, $1 \mathrm{~mL}$ 
of TRIzol was added in $1.5 \mathrm{~mL}$ eppendorf tube and vortexed. Samples were maintained at room temperature for $5 \mathrm{~min}$. To the reaction mixture $0.2 \mathrm{~mL}$ of chloroform is added and vigorously mixed for 15 seconds. The tube was allowed to stand at room temperature for $5 \mathrm{~min}$, the resulting mixture was centrifuged at $10,000 \mathrm{~g}$ for $15 \mathrm{~min}$ at 4 ${ }^{0} \mathrm{C}$. Upper aqueous phase is transferred to a new clean eppendorf tube and treated with 0.5 $\mathrm{mL}$ of isopropanol. The resultant mixture is mixed gently by inverting and incubated at room temperature for $5 \mathrm{~min}$. Samples were centrifuged at $10,000 \mathrm{~g}$ for $10 \mathrm{~min}$ at $4{ }^{0} \mathrm{C}$. Supernatant was discarded and the RNA pellet was treated with by adding $1 \mathrm{~mL}$ of 70 $\%$ ethanol. The sample was mixed gently by inverting and centrifuged for $5 \mathrm{~min}$ at 14,000 $\mathrm{g}$ at $4{ }^{0} \mathrm{C}$. Supernatant was discarded by inverting the tube on a clean tissue paper. Later, the pellet was dried by incubating in a dry bath for $5 \mathrm{~min}$ at $55{ }^{0} \mathrm{C}$. The pellet was then resuspended in $25 \mu \mathrm{L}$ of DEPC treated water. The pellet was air dried and dissolved in DEPC treated water (D.Simms et al., 1993)

\section{RT PCR}

The RT step is critical for accurate quantification and the amount of cDNA produced must accurately represent RNA input amounts (S A Bustin. 2002). A reverse transcriptase polymerase chain reaction (RTPCR) was carried out using Techno Prime system to determine the levels of Bax and Bcl2 and $\beta$-Actin mRNA expressions. The cDNA was synthesized from $2 \mu \mathrm{g}$ of RNA using the Verso cDNA synthesis kit with oligo dT primer. The reaction volume was set to $20 \mu \mathrm{L}$ and cDNA synthesis was performed at $42{ }^{\circ} \mathrm{C}$ for $60 \mathrm{~min}$, followed by $\mathrm{RT}$ inactivation at $85^{\circ} \mathrm{C}$ for $5 \mathrm{~min}$.

Table.A Primer: details

\begin{tabular}{|c|c|c|c|c|}
\hline Gene & $\begin{array}{c}\text { Primer } \\
\text { pair }\end{array}$ & Sequence & $\mathbf{T}_{\mathbf{m}}$ & $\begin{array}{c}\text { Amplicon } \\
\text { size (bp) }\end{array}$ \\
\hline $\boldsymbol{\beta}$ - Actin & FP & TCCTCCTGAGCGCAAGTACTCT & 62.1 & 153 \\
\cline { 2 - 5 } & RP & GCTCAGTAACAGTCCGCCTAGAA & 62.4 & \\
\hline \multirow{2}{*}{ Bax } & FP & GGGAGGTCAGGTGTCCATTG & 55.88 & 152 \\
And & RP & TGCTCTCGGGATAGTCACCA & 53.83 & \\
\hline Bcl2 & FP & GGTGTCCATTGAGTCACCA & 54 \\
& RP & GCAAGTACTCTCAGTAA & 53 \\
\hline
\end{tabular}

FP : Forward primer ; RP : Reverse primer

Primer source : Erofins primer

\section{PCR}

The PCR mixture (final volume of $20 \mu \mathrm{L}$ ) contained $1 \mu \mathrm{L}$ of cDNA, $10 \mu \mathrm{L}$ of Red Taq Master Mix 2x (Amplicon) and $1 \mu \mathrm{M}$ of each complementary primer specific for Bax and Bcl 2 and $\beta$-Actin (internal control) sequence. The samples were denatured at $94{ }^{\circ} \mathrm{C}$ for 5 min, and amplified using 35 cycles of $94{ }^{\circ} \mathrm{C}$ for 30 seconds each, and for $\mathrm{Bax}$ and $\mathrm{Bcl} 2$ annealing temperature was set to $49{ }^{\circ} \mathrm{C}$ and for $\beta$-Actin the annealing temperature was set to $55{ }^{\circ} \mathrm{C}$ for 30 seconds and elongation at 72 ${ }^{\circ} \mathrm{C}$ for $1 \mathrm{~min}$ followed by a final elongation at $72{ }^{\circ} \mathrm{C}$ for $10 \mathrm{~min}$. The optimal numbers of cycles have been selected for amplification of these genes experimentally so that amplifications were in the exponential range and have not reached a plateau. Ten microliters of the final amplification product 
were run on a $2 \%$ ethidium bromide-stained agarose gel and photographed. Quantification of the results were accomplished by measuring the optical density of the bands, using the computerized imaging program Image $J$. The values were normalized to $\beta$ Actin intensity levels.

\section{Results and Discussion}

\section{Isolation of bacteria}

The bacteria were isolated from homemade and commercial curd and their colonies were counted using colony counter. The results of the bacterial colonies are shown in Table-1.

The Figure 1 and Figure 2 shows the growth of bacteria from homemade and commercial curd respectively.

\section{Antiproliferative effect}

\section{Percent of inhibition}

The percent of inhibition of the samples homemade and commercial curd on the Hep G2 cell line is tabulated in Table- 2 .

The results of the MTT assay, in accordance with the percent of inhibition and concentration of the samples denotes that, the percent of inhibition is directly proportional to the concentration of the samples and hence homemade curd shows greater percent of inhibition than that of commercial curd.

Doxorubicin was chosen as a positive control. The proliferation of the cancer cells shall be inhibited by the samples showing lower value for the $\mathrm{IC}_{50}$. Standard Doxorubicin showed an $\mathrm{IC}_{50}$ value of $18.69 \mu \mathrm{M}$ inhibition in Hep G2 cells. Commercial curd and homemade curd showed $54.20 \%$ and $62.44 \%$ inhibition at higher concentration of cell free supernatant.
Acridine orange and ethidium bromide dual staining using HepG2 cell line

Acridine orange stains both live and dead cells whereas Ethidium bromide stains only cells that have lost membrane integrity. Live cells were visualized green. Early apoptotic cells stain green and contain bright green dots in the nuclei as a consequence of chromatin condensation and nuclear fragmentation. Late apoptotic cells also incorporate Ethidium bromide and therefore stain orange, but, in contrast to necrotic cells, the late apoptotic cells show condensed and often fragmented nuclei. Necrotic cells stain orange, but have a nuclear morphology resembling that of viable cells, with no condensed chromatin.

\section{Standard doxorubicin $25 \mu \mathrm{M}$}

Dual staining was examined under a fluorescent microscope. Normal cells are seen with circular nucleus uniformly distributed in the center of the cell which is seen in the control Fig 5 and 6. Fig 7, 8, 11 and 12 are showing Early stage apoptotic cells, where cell's nucleus is showing yellow-green fluorescence by Acridine orange (AO) staining and concentrated into a crescent or granular that located in one side of cells.

Staining was localized asymmetrically within the cells. In Fig 9, 10, 13 and 14 it is seen that the nucleus of cells showed orange fluorescence by $\mathrm{EtBr}$ staining and gathered in concentration and located in bias. This is late apoptotic phase. Cells that have taken up complete EtBr are the dead cells as in Fig 15 and 16.

The bacteria were isolated from homemade and commercial curd and their colonies were counted using colony counter. The percent of inhibition were calculated on the samples homemade and commercial curd with Hep G2 cell line. Dual staining technique $(\mathrm{AO} / \mathrm{EtBr})$ 
was done under the fluorescent microscope to visualize the viable cells. Staining was localized asymmetrically within the cells, cells that have taken up complete $\mathrm{EtBr}$ are recognized as dead cells. Futher the study was followed for gene regulation by Bax and $\mathrm{Bcl} 2$ gene with $\beta$-Actin as housekeeping gene. The study concludes that $\mathrm{Bcl} 2$ gene showed more fold up regulation when compared with Bax gene on the pooled homemade curd sample.

Table.1 Bacterial colony counts of samples

\begin{tabular}{|l|c|c|}
\hline Sample & Dilutions & $\begin{array}{l}\text { Colony counts } \\
\text { (CFU/g) }\end{array}$ \\
\hline \multirow{2}{*}{ Homemade Curd } & $10^{-2}$ & 267 \\
\hline \multirow{2}{*}{ Commercial Curd } & $10^{-3}$ & 158 \\
\cline { 2 - 3 } & $10^{-2}$ & 537 \\
\hline
\end{tabular}

Table.2 Percent of inhibition of curd samples

\begin{tabular}{|c|c|c|c|}
\hline \multicolumn{4}{|l|}{ Hep G2 cell line } \\
\hline Samples & Conc. in \% & $\begin{array}{l}\text { OD at } \\
590 \mathrm{~nm}\end{array}$ & $\begin{array}{l}\% \\
\text { Inhibition }\end{array}$ \\
\hline Control & 0 & 0.583 & 0.00 \\
\hline \multirow{6}{*}{$\begin{array}{l}\text { Commercial } \\
\text { curd }\end{array}$} & 1.56 & 0.510 & 12.52 \\
\hline & 3.13 & 0.458 & 21.44 \\
\hline & 6.25 & 0.376 & 35.49 \\
\hline & 12.50 & 0.341 & 41.51 \\
\hline & 25.00 & 0.304 & 47.86 \\
\hline & 50.00 & 0.267 & 54.20 \\
\hline \multirow[t]{6}{*}{ Homemade curd } & 1.56 & 0.502 & 13.83 \\
\hline & 3.13 & 0.432 & 25.90 \\
\hline & 6.25 & 0.380 & 34.82 \\
\hline & 12.50 & 0.297 & 49.06 \\
\hline & 25.00 & 0.253 & 56.60 \\
\hline & 50.00 & 0.219 & 62.44 \\
\hline
\end{tabular}


Table.3 $\mathrm{IC}_{50}$ of the Lactobacillus strain supernatants on Hep G2 cell line

\begin{tabular}{|c|c|c|c|c|}
\hline \multirow{2}{*}{$\begin{array}{l}\text { Hep G2 cell } \\
\text { line } \\
\text { Samples }\end{array}$} & \multirow[b]{2}{*}{ Conc. $\mu \mathrm{M}$} & \multirow[b]{2}{*}{$\begin{array}{l}\text { OD at } \\
590 \mathrm{~nm}\end{array}$} & \multirow[b]{2}{*}{$\begin{array}{c}\% \\
\text { Inhibition }\end{array}$} & \multirow[b]{2}{*}{$\mathrm{IC}_{50} \mu \mathrm{M}$} \\
\hline & & & & \\
\hline Control & 0 & 0.583 & 0.00 & \multirow[t]{7}{*}{18.69} \\
\hline \multirow[t]{6}{*}{ Doxorubicin } & 3.13 & 0.403 & 30.82 & \\
\hline & 6.25 & 0.366 & 37.16 & \\
\hline & 12.5 & 0.294 & 49.57 & \\
\hline & 25 & 0.223 & 61.67 & \\
\hline & 50 & 0.176 & 69.73 & \\
\hline & 100 & 0.111 & 80.89 & \\
\hline
\end{tabular}

Table.4 Relative expression of Bax and $\mathrm{Bcl} 2$ gene in homemade curd

\begin{tabular}{|c|c|c|c|c|c|}
\hline \multirow{2}{*}{ Gene } & \multirow{2}{*}{$\begin{array}{c}\text { Samples } \\
(\boldsymbol{\mu L})\end{array}$} & \multicolumn{2}{|c|}{$\begin{array}{c}\text { Band Intensity Of PCR } \\
\text { Amplicon Of Genes }\end{array}$} & Normalised & $\begin{array}{c}\text { Relative } \\
\text { Gene } \\
\end{array}$ \\
\cline { 3 - 6 } & & $\boldsymbol{\beta}$-Actin & Bax and Bcl2 & & Expression \\
\hline \multirow{3}{*}{ Bax } & $\mathbf{2 5}$ & 21786.57 & 4915.2 & 0.226 & 0.210 \\
\cline { 2 - 6 } & $\mathbf{1 2 . 5}$ & 20556.18 & 16778.76 & 0.816 & 0.759 \\
\cline { 2 - 6 } & Control & 16661.52 & 17919.18 & 1.075 & 1 \\
\hline \multirow{2}{*}{ Bcl2 } & Control & 21380.69 & 16078.93 & 0.752 & 1 \\
\cline { 2 - 6 } & $\mathbf{1 2}$ & 17729.28 & 11083.71 & 0.625 & 0.831 \\
\hline & $\mathbf{2 5}$ & 16323.66 & 5469.08 & 0.335 & 0.446 \\
\hline
\end{tabular}

Table.5 Relative expression of Bax and $\mathrm{Bcl} 2$ gene in commercial curd

\begin{tabular}{|c|c|c|c|c|c|}
\hline \multirow{2}{*}{ Gene } & $\begin{array}{c}\text { Samples } \\
(\boldsymbol{\mu L})\end{array}$ & \multicolumn{2}{|c|}{$\begin{array}{c}\text { Band Intensity Of PCR } \\
\text { Amplicon Of Genes }\end{array}$} & Normalised & $\begin{array}{c}\text { Relative Gene } \\
\text { Expression }\end{array}$ \\
\hline \multirow{3}{*}{ Bax } & 50 & 14189.40 & 6194.32 & 0.44 & 0.409 \\
\cline { 2 - 6 } & 25 & 15784.27 & 8547.76 & 0.54 & 0.507 \\
\cline { 2 - 6 } & Control & 16867.00 & 18023.49 & 1.07 & 1 \\
\hline \multirow{3}{*}{ Bcl2 } & Control & 14266.15 & 15215.47 & 1.07 & 1 \\
\cline { 2 - 6 } & 25 & 15280.23 & 11787.57 & 0.77 & 0.723 \\
\cline { 2 - 5 } & 50 & 14229.38 & 8705.61 & 0.61 & 0.574 \\
\hline
\end{tabular}




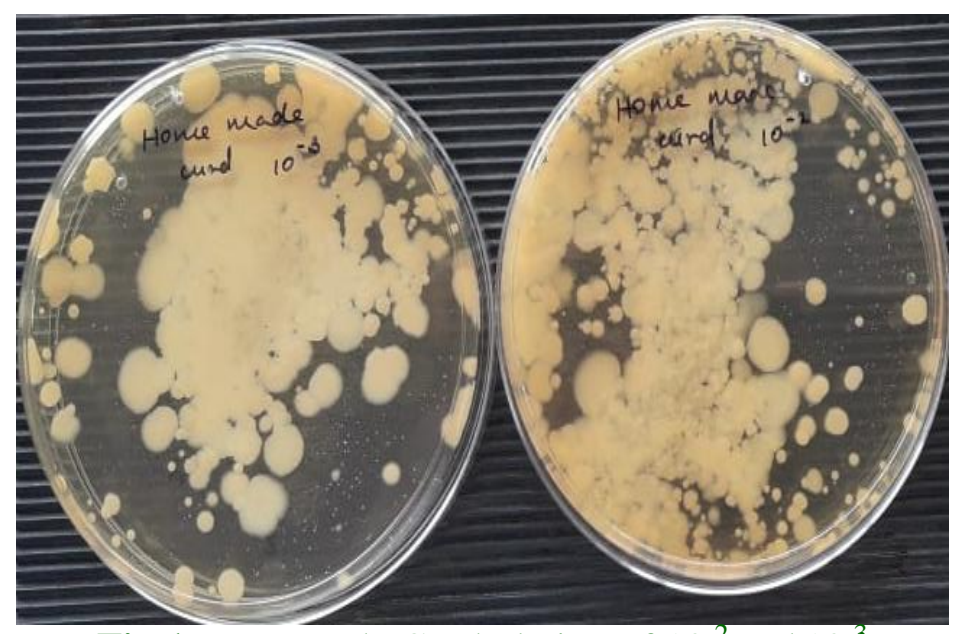

Fig.1 Homemade Curd plating of $10^{-2}$ and $10^{-3}$

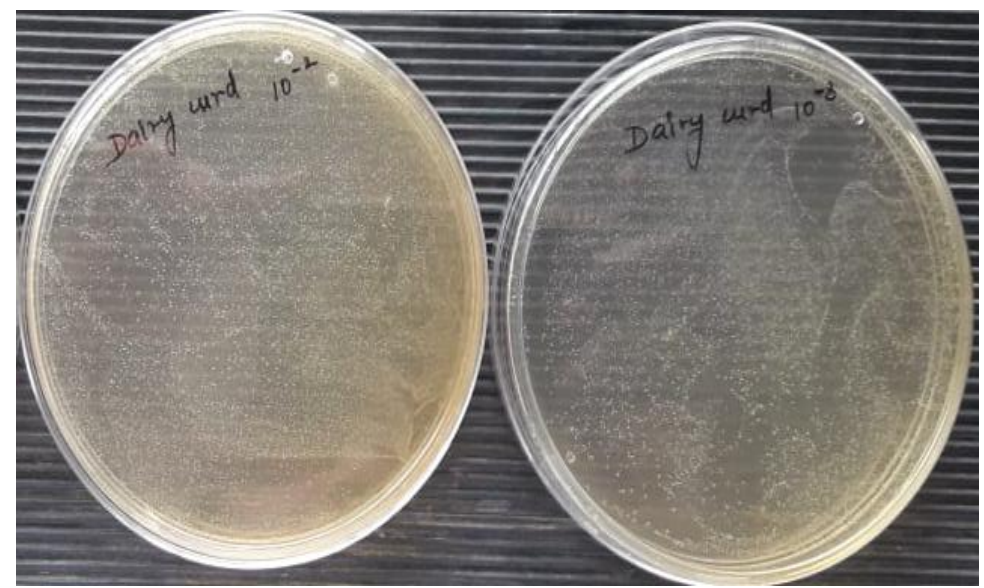

Fig.2 Commercial curd plating of $10^{-2}$ and $10^{-3}$

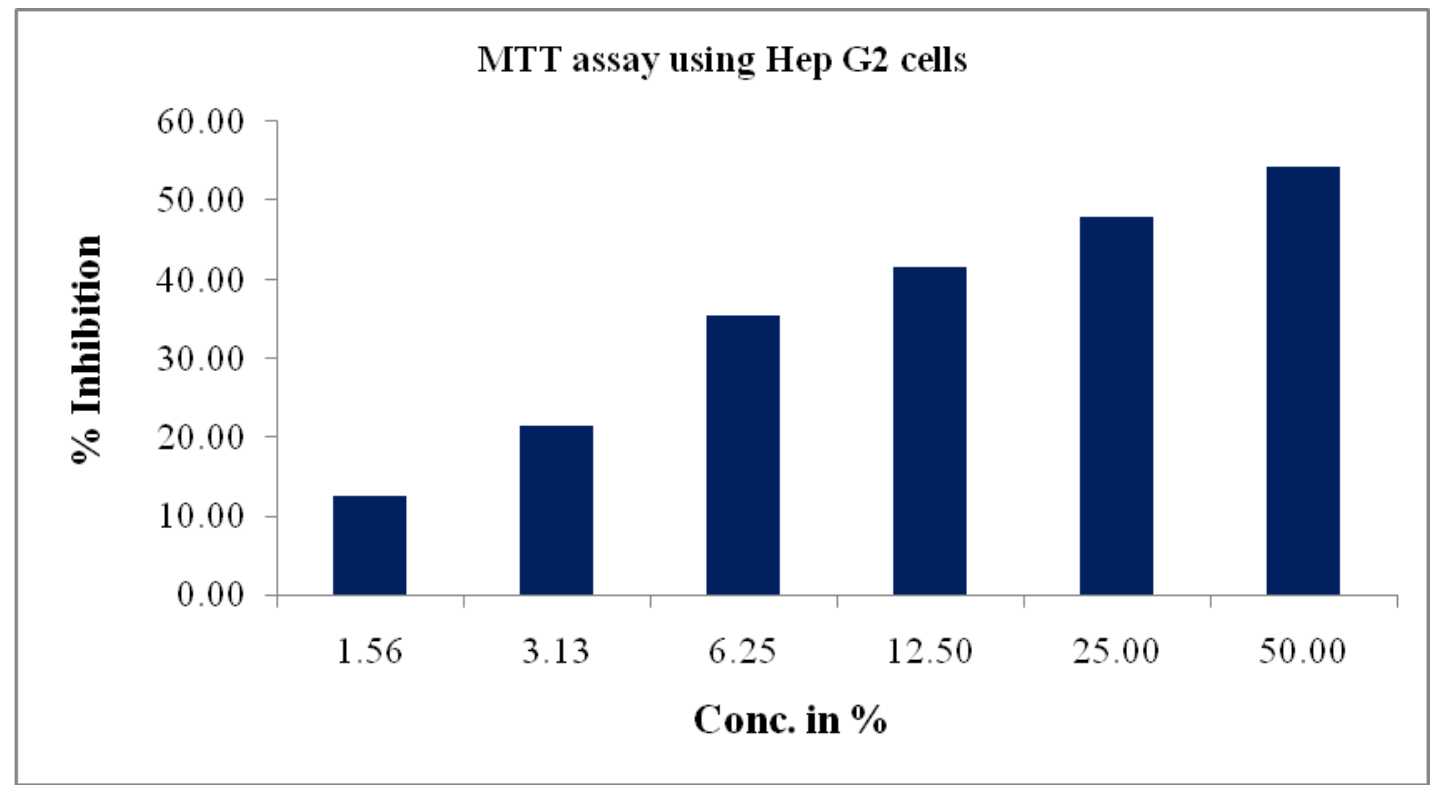

Figure.3 Bar graph for percent of inhibition 


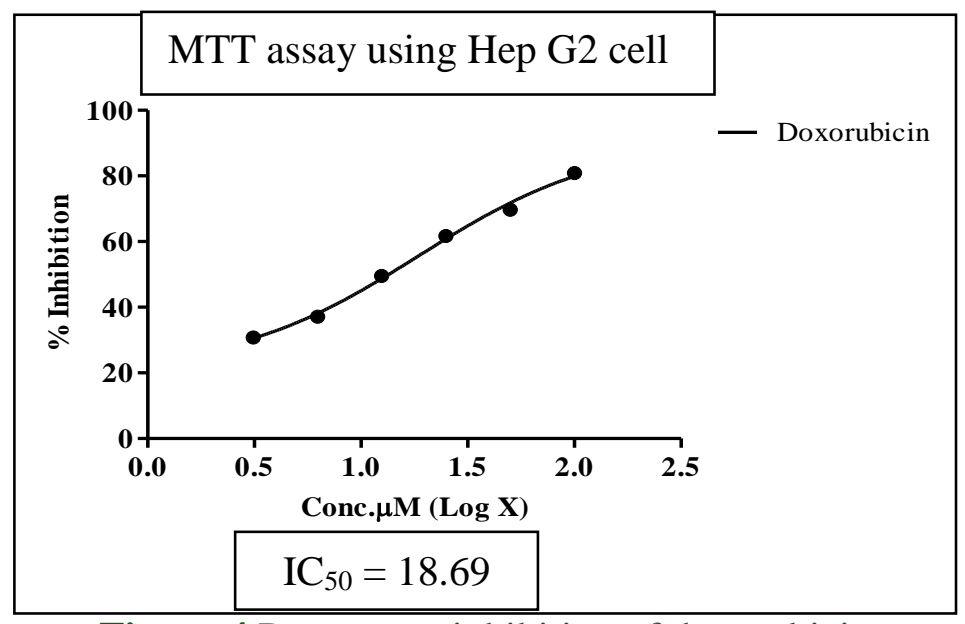

Figure.4 Percentage inhibition of doxorubicin

Control HepG2 cells

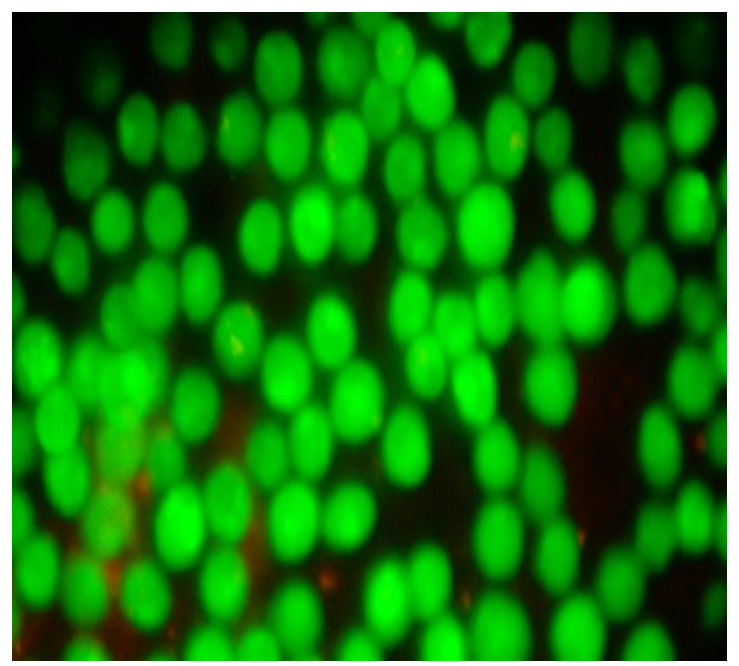

Figure.5 Normal cells - treated cells

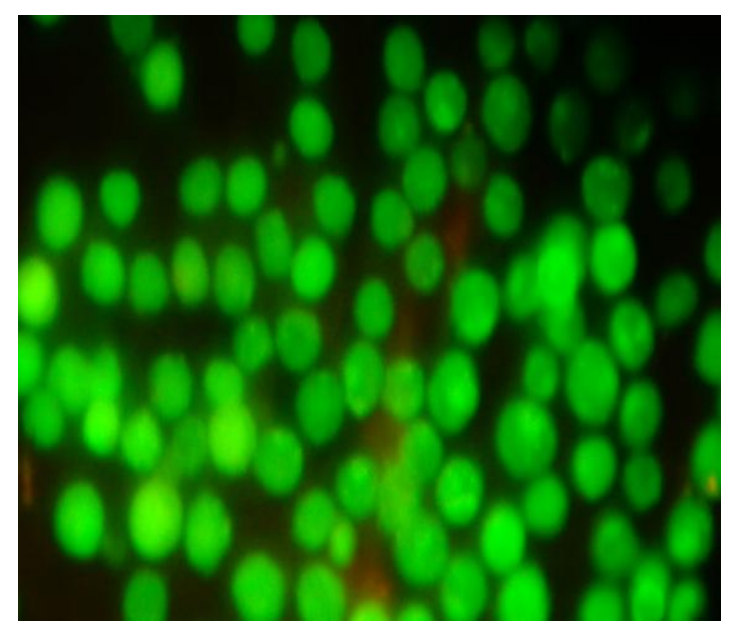

Figure.6 Normal cells - untreated cells 
Conc. $12.5 \%$ of homemade curd

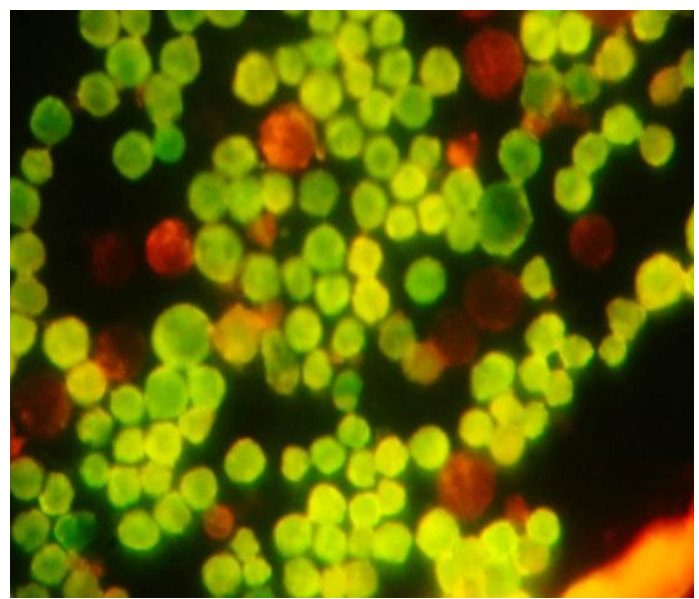

Figure.7 Early stage apoptotic phase - treated cells

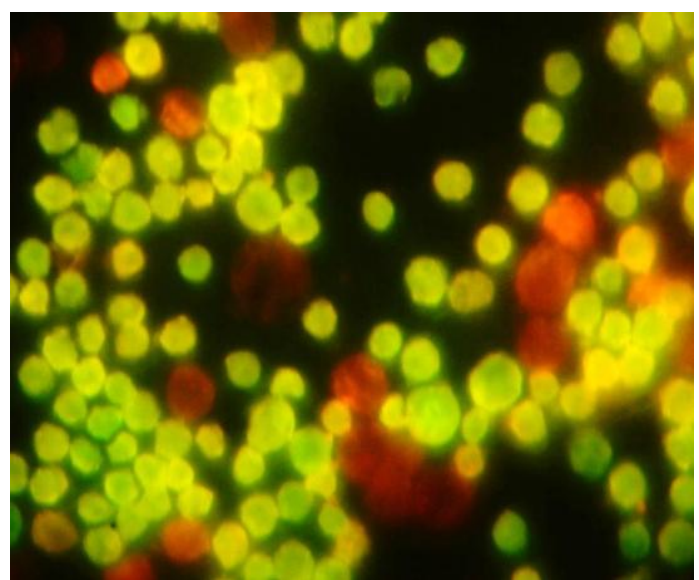

Figure.8 Early stage apoptotic phase - untreated cells

Conc. $25 \%$ of homemade curd

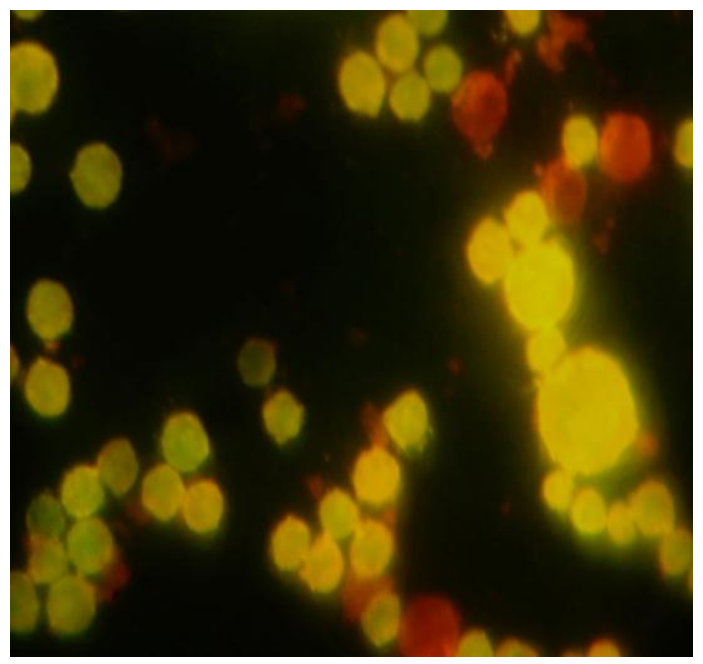

Figure.9 Late stage apoptotic phase -treated cells 


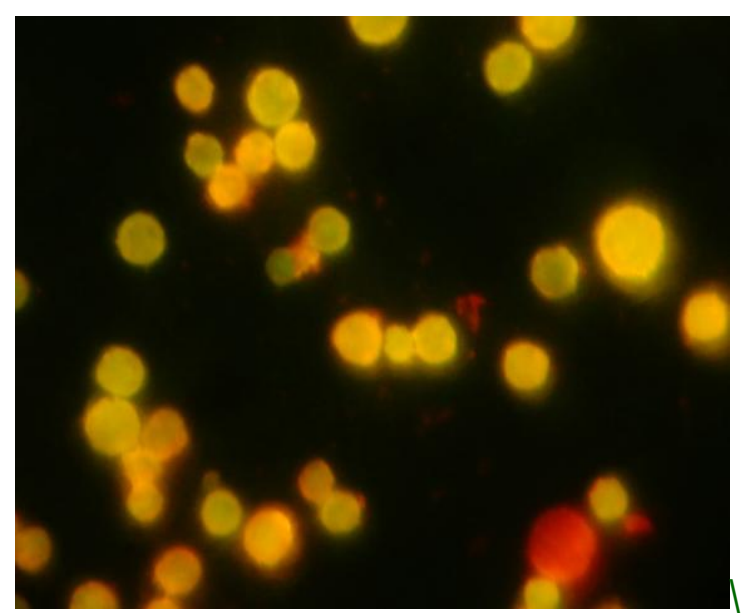

Figure.10 Late apoptotic phase - untreated cells

Conc. $25 \%$ of commercial curd

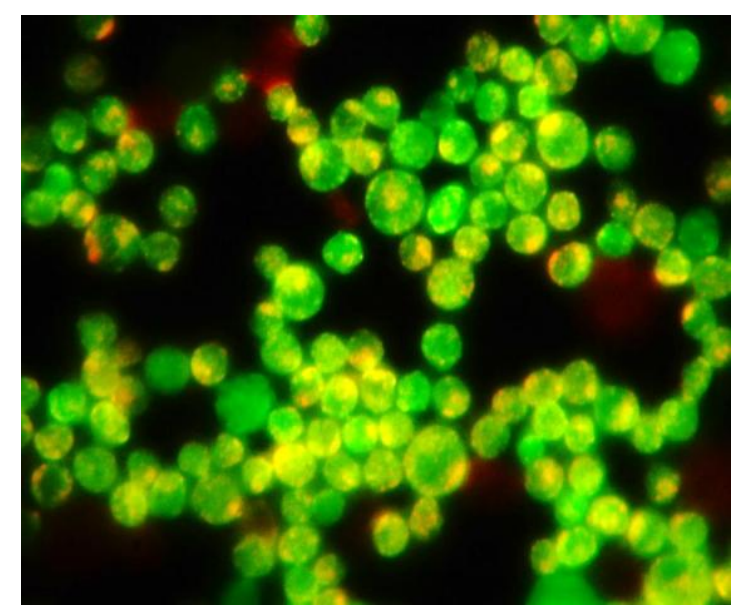

Figure.11 Early apoptotic cells - treated cells

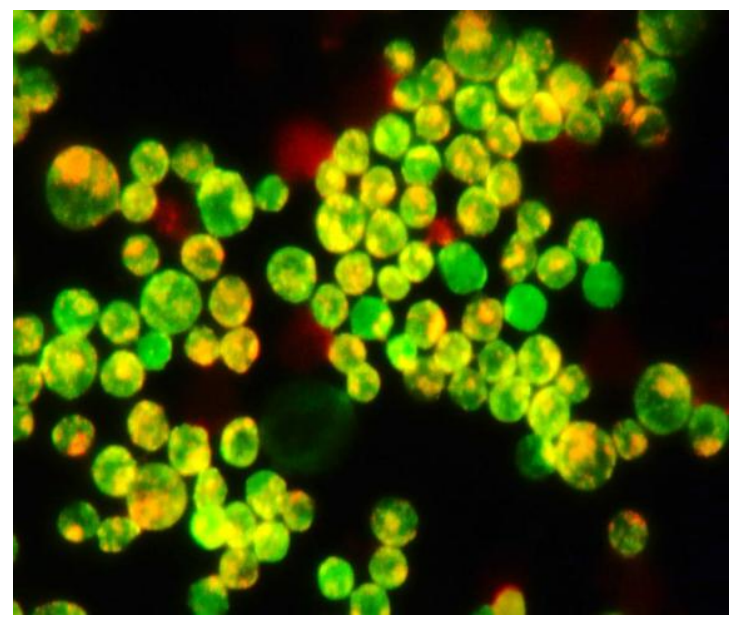

Figure.12 Early stage apoptotic cell - untreated cells 
Conc. $50 \%$ of commercial curd

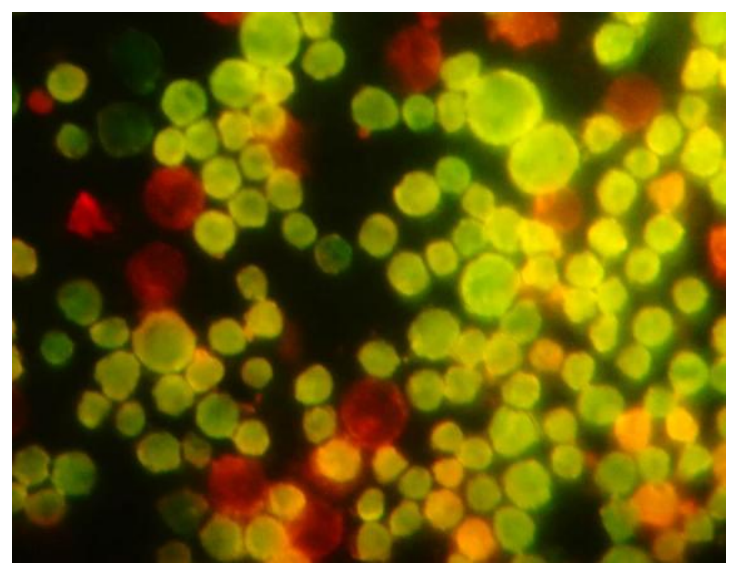

Figure.13 Late stage apoptotic phase - treated cells

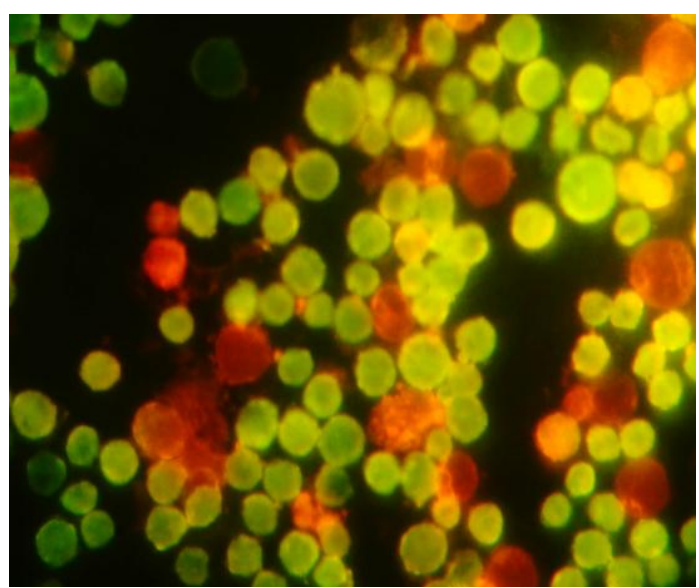

Figure.14 Late stage apoptotic phase - untreated cells

Standard Doxorubicin $25 \mu \mathrm{M}$

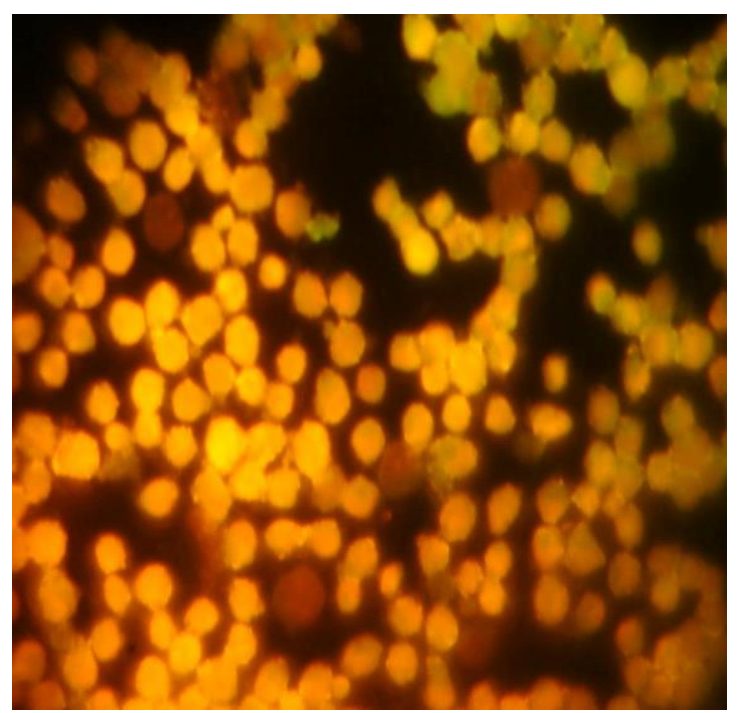

Figure.15 Dead cells - treated cells 


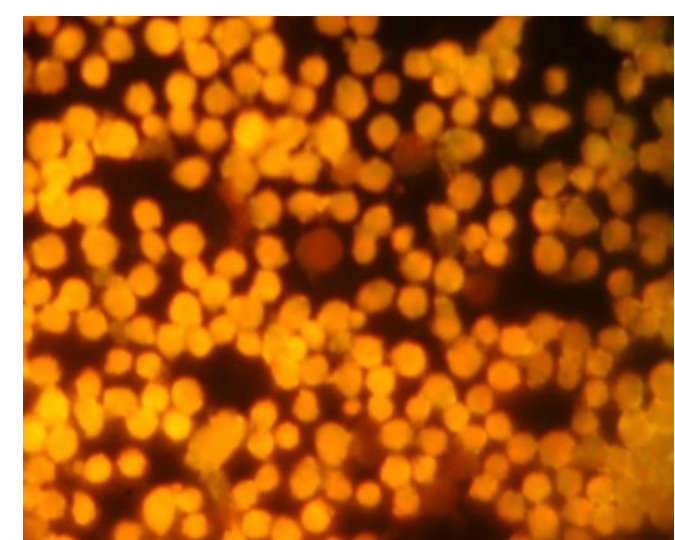

Figure.16 Dead cells - untreated cells

Comparison of amplicons - Amplicons of homemade curd
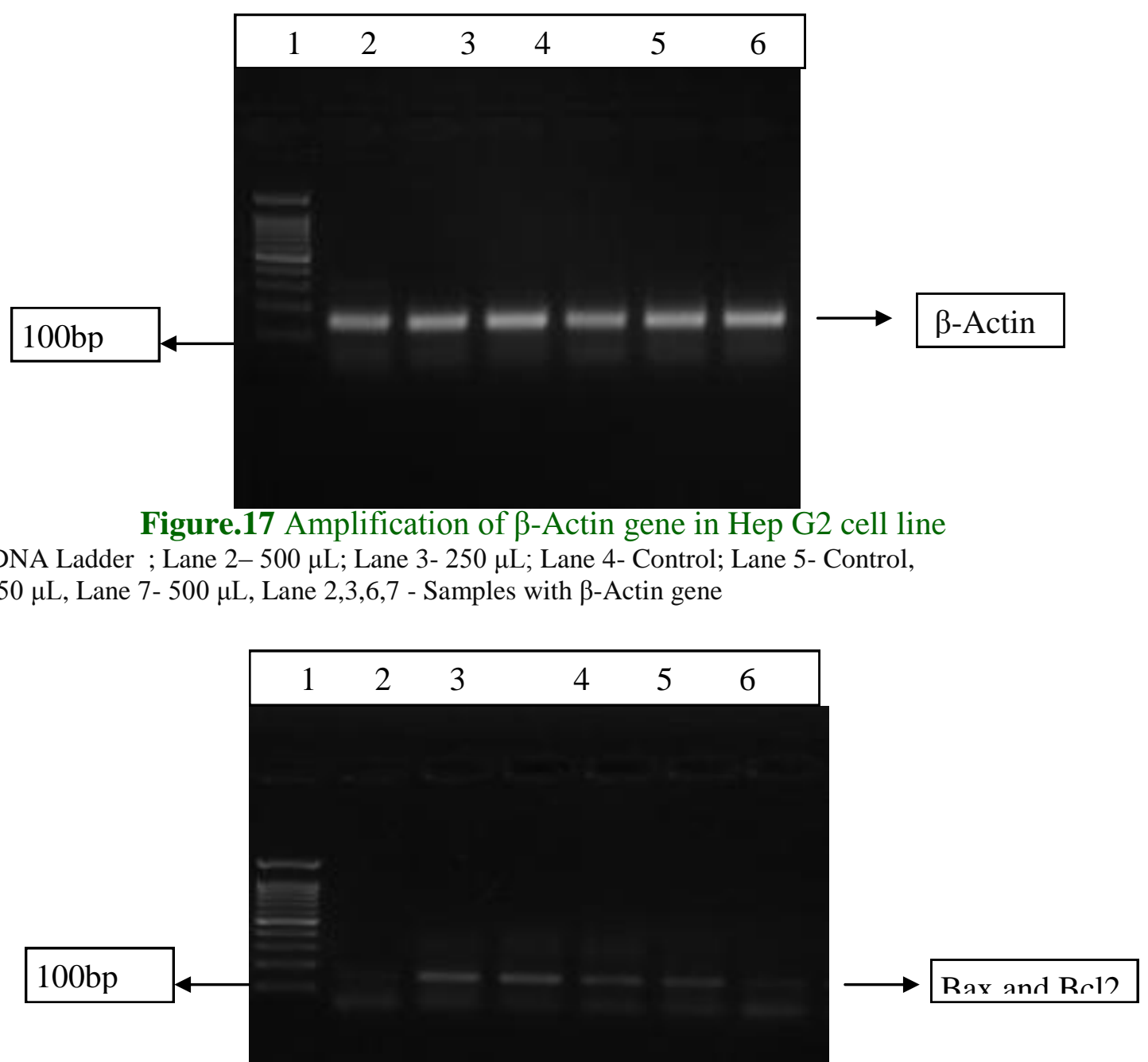

Figure.18 Amplification of Bax and Bcl 2 gene in Hep G2 cell line

Lane 1- DNA Ladder ; Lane 2-500 $\mu \mathrm{L}$; Lane 3-250 $\mu \mathrm{L}$; Lane 4- Control; Lane 5- Control, Lane 6-250 $\mu \mathrm{L}$, Lane 7- $500 \mu \mathrm{L}$, Lane 2,3 - Samples with Bax gene ; Lane 6,7 - Samples with Bcl2 gene 


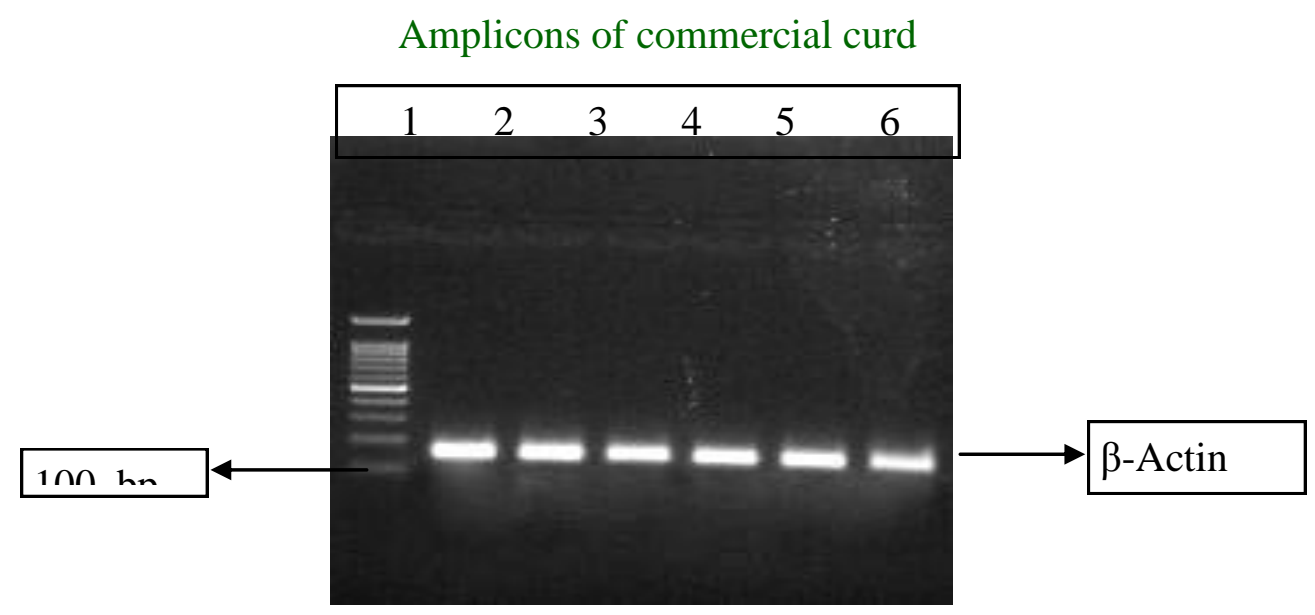

Figure.19 Amplification of $\beta$-Actin gene in Hep G2 Cell line

Lane 1- DNA Ladder ; Lane 2- $500 \mu \mathrm{L}$; Lane 3-250 $\mu \mathrm{L}$; Lane 4- Control; Lane 5- Control, Lane 6-250 $\mu \mathrm{L}$, Lane 7- $500 \mu \mathrm{L}$, Lane 2,3,6,7 - Samples with $\beta$-Actin gene

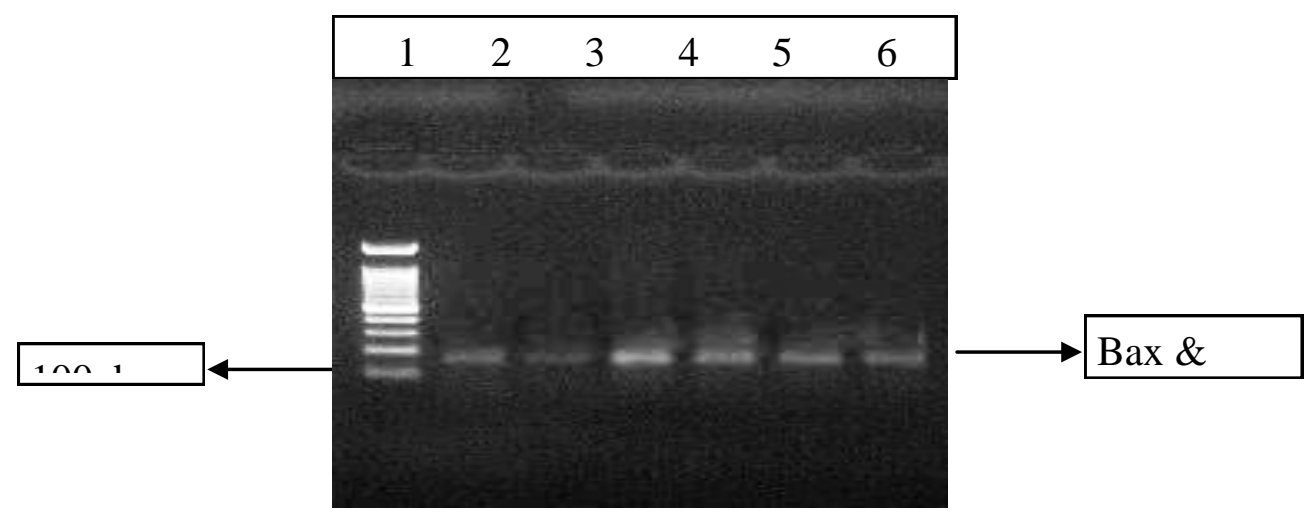

Figure.20 Amplification of Bax and Bcl2 gene in Hep G2 Cell line

Lane 1- DNA Ladder ; Lane 2- $500 \mu \mathrm{L}$; Lane 3-250 $\mu \mathrm{L}$; Lane 4- Control; Lane 5- Control, Lane 6-250 $\mu \mathrm{L}$, Lane 7- $500 \mu \mathrm{L}$, Lane 2,3 - Samples with Bax gene ; Lane 6,7 - Samples with Bcl2 gene

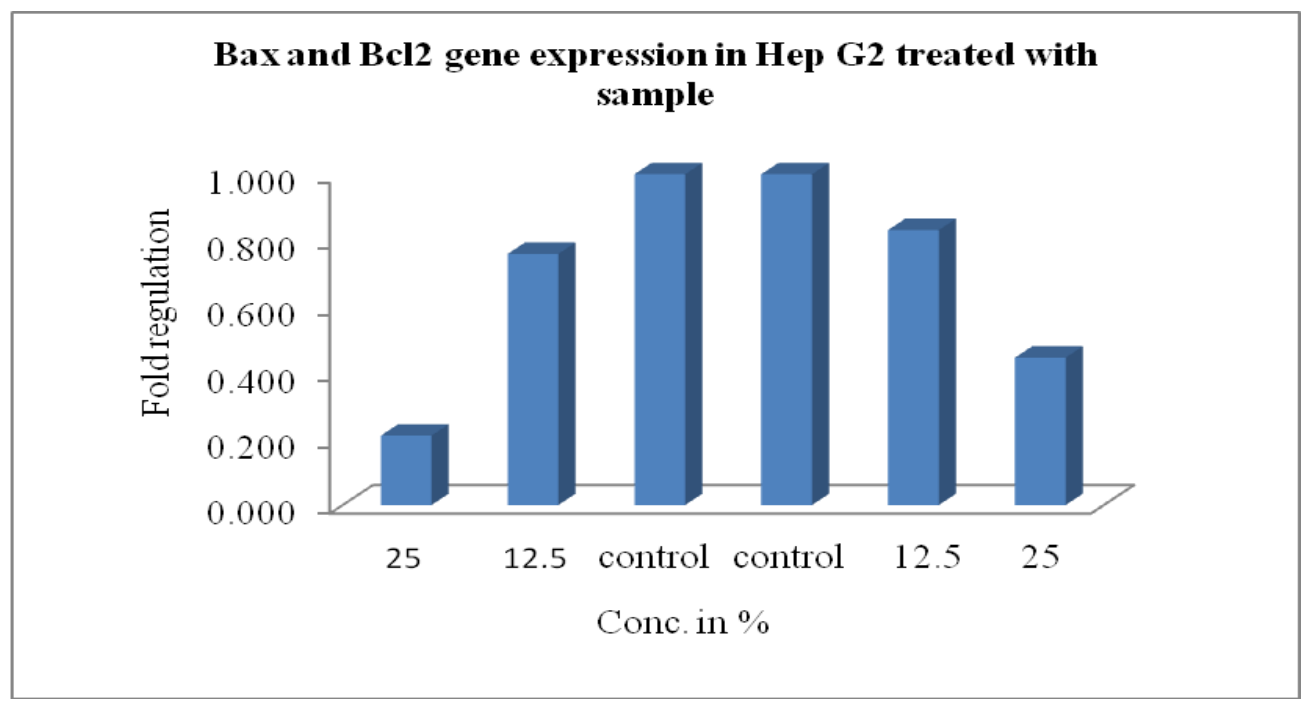

Figure.21 Fold regulation of Bax and Bcl2 gene in homemade curd 


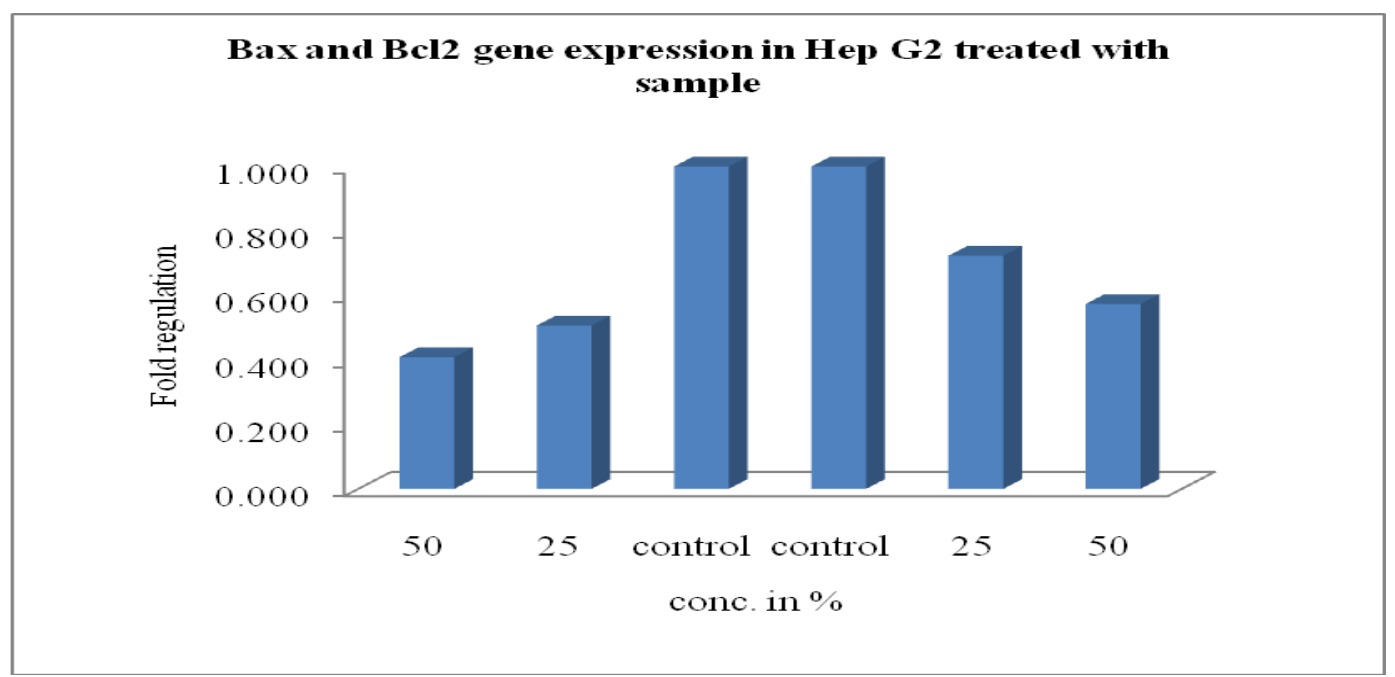

Figure.22 Relative expression of $\mathrm{Bax}$ and $\mathrm{Bcl} 2$ gene in commercial curd

In conclusion, our study disclosed that the probiotic bacteria was isolated from two different sources such as homemade curd and commercial curd and was analyzed for their antiproliferative activity by MTT assay on Hep $\mathrm{G} 2$ cell line. Based on the $\mathrm{IC}_{50}$ value, homemade curd shows more percent of inhibition than commercial curd. In this study, effect of Homemade curd and commercial curd for expression of $\mathrm{Bax}$ and $\mathrm{Bcl} 2$ gene was studied in Hep G2 cell by RT-PCR. The internal control $\beta$-Actin was used to normalize the gene expression. Bcl2 showed fold up regulation when compared to Bax. The results of this study revealed that the MTT assay for the probiotic bacterium isolated from the sample has better cytotoxicity effect.

\section{Acknowledgement}

We are thankful to Skanda Life Science Pvt.Ltd. Bengaluru, for providing us the laboratory facilities to carry out this project.

\section{References}

Bustin, S A. 2002 Quantification of mRNA using real-time reverse transcription PCR (RT-PCR): trends and problems, 29:23-39.
Dicks LMT and Botes M, 2010. Probiotic lactic acid bacteria in gastro-intestinal tract: health benefits, safety and mode of action. Beneficial Microbes, 1: 1129.

Kuan Liu, Peng-cheng Liu, Run Liu, Xing Wu. 2015 Dual AO/ED staining to detect apoptosis in osteosarcoma cells compared with flow cytometry, 21:1520.

Maryam

Poormontaseri, Saeid Hosseinzadeh, Seyed Shahram Shekarforoush, and Tahereh Kalantari, 2017. The effects of probiotic Bacillus subtilis on the cytotoxicity of Clostridium perfringens type a in Caco-2 cell culture, 17: 150.

Nimmy Kumar, Subhankar Biswas, Asha Elizabeth Mathew, Subin Varhese, Jessy Elizabeth, K. Nada Kumar, Jesil Mathew Arajani, Richard Lobo. 2016 Pro apoptotic and cytotoxic effect of enriched fraction of Elytranthe parasitica (L). Danser against HepG2 Hepatocellular carcinoma, 16:420.

Parisa Shokryazdan, Mohammad Faseleh Jahromi, Fatemeh Bashokouh, Zulkifli Idrus, Juan Boo Liang, 2017. Antiproliferation effects and antioxidant activity of two 
new Lactobacillus strains, 21

Sahar Karami, Mohammad Roayaei, Hosna Hamzavi, Mahmoud Bahmani, Hassan Hassanzad-Azar, Mahmoodnia Leila, Mahmoud Rafieian-Kopaei, 2017 Isolation and identification of probiotic Lactobacillus from local dairy and evaluating their antagonistic effect on pathogens, 7:137-41.

Simms, D., PE Cizdzial, P Chomczynki. 1993 TRIZOL :A new reagent for optimal single step isolation of RNA, 4:99102.

\section{How to cite this article:}

Ramesh Babu. N. G., K. A. Simrah Fathima, V. Nandhini and Nandhini. V. 2020. Cytotoxicity Effects of Lactobacillus Acidophilus on Hep G2 Cell Line and its Effects on Gene Regulation with Bax \& Bcl2. Int.J.Curr.Microbiol.App.Sci. 9(05): 891-906.

doi: https://doi.org/10.20546/ijcmas.2020.905.098 